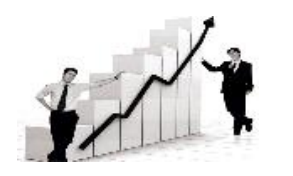

Visit us - www.researchjournal.co.in — DOI : 10.15740/HAS/IRJAES/7.1/63-66

International Research Journal of Agricultural Economics and Statistics

Volume 7 | Issue 1 | March, 2016 | 63-66 e ISSN-2231-6434

\title{
Research Paper Yield evaluation of early duration rice variety Sushk Samrat on farmers in Faizabad district of Uttar Pradesh
}

See end of the paper for authors' affiliations

Correspondence to : ALOK PANDEY

Crop Research Station (NDUAT), Masodha, FAIZABAD (U.P.) INDIA Email: alokpandey77@ live.com

Paper History :

Received : 15.01.2016; Revised : 23.01.2016; Accepted : 01.02.2016
AbStRact : Front line demonstrations (FLDs) were conducted in Faizabad district of Uttar Pradesh to asses performance of short duration rice variety Sushk Samrat on Farmers field in target environment i.e. rainfed upland during Kharif 2011 and 2012. The socio-economic survey of district revealed the real problem associated with rice cultivation. Farmers of the study areas were resource poor and they are still growing local land races in rainfed upland ecosystem. In view of the above mentioned facts frontline demonstrations on newly developed short duration rice variety 'Sushk Samrat' was conducted to improve rice productivity and bridging gap between potential yield and farmers yield of rice. Result of two consecutive years of the FLD's revealed that rice variety Sushk Samrat posses drought resistant coupled with high yielding capacity and it out yielded farmers variety in all the demonstrations. The average of two seasons data revealed that 34.77 per cent higher grain yield of rice $(28.87 \mathrm{q} / \mathrm{ha})$ is recorded in demonstrations as compared to farmers' practice $(21.42 \mathrm{q} / \mathrm{ha})$. The high positive value $(9.76 \%)$ of technology index indicated that technology is highly viable for rice cultivation in rainfed upland ecosystem of Faizabad district of Uttar Pradesh.

KEY WoRDS : FLD's, Rainfed, Sushk samrat

How To Cite This PAPer : Verma, D.K., Verma, Saurabh, Pandey, Alok, Giri, S.P., Tripathi, R.M., Dwivedi, J.L., Singh, Janardan, Singh, R.B. and Gopal, Ram (2016). Yield evaluation of early duration rice variety Sushk Samrat on farmers in Faizabad district of Uttar Pradesh. Internat. Res. J. Agric. Eco. \& Stat., 7 (1) : 63-66. 